\title{
Covered Metal Stent after Dysfunction of Uncovered Stents for Palliation of Gastrointestinal Malignant Obstruction
}

\author{
Marta Patita ${ }^{a}$ Rui Castro $^{b}$ Diogo Libânio $^{b, c}$ Rui Pedro Bastos ${ }^{b}$ Rui Silva $^{b}$ \\ Mário Dinis-Ribeiro ${ }^{b, c}$ Pedro Pimentel-Nunes ${ }^{b-d}$ \\ ${ }^{a}$ Gastroenterology Department, Hospital Garcia de Orta, Almada, Portugal; ${ }^{b}$ Gastroenterology Department, \\ Portuguese Oncology Institute of Porto, Porto, Portugal; 'CCenter for Research in Health Technologies and \\ Information Systems, Porto, Portugal; d Surgery and Physiology Department, Faculty of Medicine, University of \\ Porto, Porto, Portugal
}

\section{Keywords}

Colon obstruction - Gastric outlet obstruction .

Gastrointestinal tumors · Self-expanding metal stent

\section{Abstract}

Background: Self-expanding metal stents (SEMS) have been used for the palliative treatment of malignant gastrointestinal tract obstruction. However, restenosis or incomplete expansion of a first stent is a frequent complication, and the effectiveness of reintervention with placement of a second stent is still controversial. Objective: To evaluate the clinical outcomes of covered SEMS (cSEMS) placement after dysfunction of uncovered SEMS (USEMS) by the stent-in-stent technique. Patients and Methods: We retrospectively studied a consecutive series of patients receiving palliative treatment for malignant gastrointestinal obstruction with cSEMS placement after uSEMS dysfunction in a tertiary center from January 2013 to August 2018. Technical and clinical success, time of patency, and adverse events were analyzed. Results: Twelve patients were included; their mean age was $60 \pm 9$ years. Eleven patients had gastric outlet obstruction, and 1 patient had compression of the transverse colon due to gastric neoplasia. In 5 cases, there was absence of early clinical success with uSEMS and stent dysfunction in 7 cases (median patency time: 81 days). There was 100\% technical success and $91.7 \%$ clinical success after cSEMS placement. There were no adverse events nor need for reintervention. The median patency time after placement of both stents was 163 days (vs. 71 days with the initial stent). Conclusion: CSEMS placement after uSEMS dysfunction is technically feasible and a clinically effective treatment for patients with recurrent malignant gastrointestinal obstruction, with good stent patency in the medium/long term. This approach seems to be safe and without increase in adverse effects.

\footnotetext{
(c) 2020 Sociedade Portuguesa de Gastrenterologia Published by S. Karger AG, Basel
}

\section{Próteses Metálicas Cobertas Após Disfunção de Próteses Não-Cobertas Para Paliação de Neoplasias Gastrointestinais Obstrutivas}

\section{Palavras-Chave}

Neoplasias gastrointestinais · Obstrução cólica • Obstrução do trato de saída gástrico · Prótese metálica coberta

\begin{tabular}{ll}
\hline KARGER & $\begin{array}{l}\text { ( ) 2020 Sociedade Portuguesa de Gastrenterologia } \\
\text { Published by S. Karger AG, Basel }\end{array}$ \\
karger@karger.com & This article is licensed under the Creative Commons Attribution- \\
www.karger.com/pjg & $\begin{array}{l}\text { NonCommercial-NoDerivatives 4.0 International License (CC BY- } \\
\text { NC-ND) (http://www.karger.com/Services/OpenAccessLicense). } \\
\text { Usage and distribution for commercial purposes as well as any dis- } \\
\text { tribution of modified material requires written permission. }\end{array}$ \\
BOPEN ACCESS &
\end{tabular}




\section{Resumo}

Introdução: As próteses metálicas autoexpansíveis (PMAE) têm sido utilizadas para a paliação de obstruções malignas do trato gastrointestinal. No entanto, a reestenose ou a expansão incompleta das próteses é uma complicação frequente e a eficácia de uma reintervenção com a colocação de uma segunda prótese é ainda controversa. Objetivo: Avaliar os resultados clínicos da colocação de PMAE cobertas (cPMAE) após disfunção de PMAE não-cobertas (ncPMAE) pela técnica de stent-in-stent. Métodos: Estudo retrospetivo, incluindo uma série consecutiva de doentes que colocaram cPMAE após disfunção ncPMAE para paliação de obstrução gastrointestinal maligna, num centro terciário, de janeiro/2013 a agosto/2018. Foram avaliados o sucesso técnico e clínico, o tempo de patência e os eventos adversos. Resultados: Foram incluídos 12 doentes, com uma idade média de $60 \pm 9$ anos. Onze doentes apresentavam obstrução do trato de saída gástrico e um doente compressão extrínseca do cólon transverso por neoplasia gástrica. Em 5 doentes verificou-se ausência de sucesso clínico precoce com ncPMAE e, em 7 casos, disfunção da prótese (tempo mediano de patência de 81 dias). Houve 100\% de sucesso técnico e 91,7\% de sucesso clínico após a colocação do cPMAE. Não se registaram eventos adversos ou necessidade de reintervenção. O tempo médio de patência após a colocação de ambas as próteses foi de 163 dias (vs. 71 com prótese inicial). Conclusão: A colocação de cPMAE após disfunção de ncPMAE é tecnicamente viável e representa um tratamento eficaz em doentes com obstrução gastrointestinal maligna recorrente, com boa patência da prótese a médio/ longo prazo. Esta abordagem parece ser segura, sem aumento de eventos adversos.

(C) 2020 Sociedade Portuguesa de Gastrenterologia Publicado por S. Karger AG, Basel

\section{Introduction}

Gastrointestinal (GI) tumors, including colorectal, pancreatic, and gastric cancers, are among the most common neoplasms worldwide [1]. These malignancies are often diagnosed at advanced stage and therefore only amenable to palliative/symptomatic treatment $[2,3]$. In the past, surgical gastrojejunostomy has been the standard therapy in gastric outlet obstruction (GOO), a frequent complication of advanced gastric and pancreaticobiliary cancer. Similar to colorectal malignant obstructions, surgery was formerly the only option. Although associated with good functional outcome and symptom relief, these treatment modalities carry significant morbidity [4-8]. In the last 2 decades, placement of a selfexpandable metal stent (SEMS) has emerged as a safe alternative to bypass surgery, with rapid relief of obstructive symptoms, fewer postprocedural complications, shorter hospital stay, and lower costs, although late complications and the need of reintervention is higher [5, $9,10]$.

Endoscopic stenting has been reported to have a high rate of technical success (98-100\%). Nevertheless, clinical success is not as high (84-91\%), and some patients maintain obstructive complaints after the procedure $[11,12]$. In fact, early restenosis, whether due to incomplete stent expansion or overgrowth/ingrowth, is a problem encountered by patients and endoscopists, which can be treated with placement of a second stent $[4,13]$. Various stents have been designed, but they can be divided broadly into covered SEMS (cSEMS) and uncovered SEMS (uSEMS). Uncovered, rather than covered, metal stents are commonly used for palliation of malignant GI obstruction because of the lower risk of stent migration, but the risk of tumor ingrowth is a major drawback. Still, current evidence and European recommendations state that cSEMS and USEMS are equally effective and safe $[14,15]$.

In a large series, our group previously showed that peritoneal carcinomatosis was associated with early and late clinical failure, and stent dysfunction was reported in $13 \%$ [11]. Some studies evaluated the technical and clinical success of second stent placement by the stent-in-stent technique after dysfunction of the first stent [16-22]. Our purpose was to describe the technical feasibility, clinical outcome, and adverse events of using specifically a cSEMS in a series of patients with recurrence of obstructive symptoms after uSEMS failure or dysfunction for palliation of malignant GI obstruction.

\section{Patients and Methods}

\section{Study Design and Selection of Patients}

We performed a retrospective study of consecutive patients undergoing either gastroduodenal or colorectal cSEMS placement following uSEMS dysfunction for palliation of malignant GI obstruction in a tertiary-care medical center (Instituto Português de Oncologia do Porto Francisco Gentil, E.P.E.) in the last 5 years (from January 2013 to August 2018). Inclusion criteria were patients with uSEMS dysfunction leading to recurrence of obstructive GI symptoms treated with cSEMS placement (stent-in-stent technique). Patients meeting inclusion criteria were not surgical candidates on the basis of the presence of advanced, metastatic disease, or medical comorbidity, or endoscopic rather than surgi-
Patita/Castro/Libânio/Bastos/Silva/ Dinis-Ribeiro/Pimentel-Nunes 
Table 1. Characteristics of the patients and stents

\begin{tabular}{|c|c|c|c|c|c|c|c|c|c|}
\hline $\begin{array}{l}\text { Patient } \\
\text { No. }\end{array}$ & $\begin{array}{l}\text { Sex, age, } \\
\text { ECOG }\end{array}$ & $\begin{array}{l}\text { Primary } \\
\text { tumor }\end{array}$ & $\begin{array}{l}\text { Site of } \\
\text { obstruction }\end{array}$ & $\begin{array}{l}\text { Previous } \\
\text { treatment }\end{array}$ & $\begin{array}{l}\text { Carcino- } \\
\text { matosis }\end{array}$ & uSEMS & $\begin{array}{l}\text { Time to } \\
\text { uSEMS } \\
\text { dysfunction }\end{array}$ & $\begin{array}{l}\text { Clip to fix } \\
\text { the mesh of } \\
\text { both stents }\end{array}$ & $\begin{array}{l}\text { Survival } \\
\text { after } \\
\text { cSEMS }\end{array}$ \\
\hline 2 & $\begin{array}{l}M, 60 y \\
3\end{array}$ & Gastric & $\begin{array}{l}\text { Esophago- } \\
\text { jejunal } \\
\text { anastomosis }\end{array}$ & $\begin{array}{l}\text { Surgery + } \\
\text { chemo./RT }\end{array}$ & Yes & $\begin{array}{l}\text { Evolution }^{\circledR}(\text { Cook }) \\
\text { Duodenal } 120 \times 22 \mathrm{~mm}\end{array}$ & $1 \mathrm{~d}$ & No & $\begin{array}{l}38 \mathrm{~d} \\
\text { (alive) }\end{array}$ \\
\hline 3 & $\begin{array}{l}M, 75 y \\
1\end{array}$ & Gastric & Pylorus & Chemo. & Yes & $\begin{array}{l}\text { Evolution }^{\circledR}(\text { Cook }) \\
\text { Duodenal } 90 \times 22 \mathrm{~mm}\end{array}$ & $224 \mathrm{~d}$ & No & $\begin{array}{l}220 \mathrm{~d} \\
\text { (alive) }\end{array}$ \\
\hline 4 & $\begin{array}{l}M, 52 y \\
2\end{array}$ & Gastric & Pylorus & Chemo. & Yes & $\begin{array}{l}\text { Evolution }^{\circledR}(\text { Cook }) \\
\text { Duodenal } 90 \times 22 \mathrm{~mm}\end{array}$ & $1 \mathrm{~d}$ & No & $\begin{array}{l}179 \mathrm{~d} \\
\text { (alive) }\end{array}$ \\
\hline 5 & $\begin{array}{l}M, 68 y \\
2\end{array}$ & Gastric & Pylorus & Chemo. & Yes & $\begin{array}{l}\text { Evolution }^{\circledR}(\text { Cook }) \\
\text { Duodenal } 90 \times 22 \mathrm{~mm}\end{array}$ & $53 \mathrm{~d}$ & No & $\begin{array}{l}16 \mathrm{~d} \\
(\text { dead })\end{array}$ \\
\hline 7 & $\begin{array}{l}M, 63 y \\
2\end{array}$ & Gastric & Pylorus & Chemo. & No & $\begin{array}{l}\text { 1st: Evolution }{ }^{\circledR}(\text { Cook }) \\
\text { Duodenal } 120 \times 22 \mathrm{~mm} \\
\text { 2nd: Evolution }{ }^{\circledR}(\text { Cook }) \\
\text { Duodenal } 120 \times 22 \mathrm{~mm}^{1}\end{array}$ & $98 \mathrm{~d}$ & Yes & $\begin{array}{l}62 \mathrm{~d} \\
(\text { dead })\end{array}$ \\
\hline 8 & $\begin{array}{l}\text { F, } 55 y \\
1\end{array}$ & Gastric & Pylorus & Chemo. & Yes & $\begin{array}{l}\text { Evolution }{ }^{\circledR}(\text { Cook }) \\
\text { Duodenal } 90 \times 22 \mathrm{~mm}(\text { Cook })\end{array}$ & $1 \mathrm{~d}$ & No & $\begin{array}{l}233 \mathrm{~d} \\
\text { (alive) }\end{array}$ \\
\hline 9 & $\begin{array}{l}F, 39 y \\
2\end{array}$ & Gastric & Pylorus & Chemo. & Yes & $\begin{array}{l}\text { Evolution }^{\circledR}(\text { Cook }) \\
\text { Duodenal } 90 \times 22 \mathrm{~mm}\end{array}$ & $1 \mathrm{~d}$ & No & $\begin{array}{l}138 \mathrm{~d} \\
(\mathrm{dead})\end{array}$ \\
\hline 10 & $\begin{array}{l}M, 60 y \\
1\end{array}$ & Gastric & Pylorus & Chemo. & No & $\begin{array}{l}\text { 1st: WallFlex }{ }^{\mathrm{TM}}\left(\text { Boston }^{\circledR}\right) \\
\text { Duodenal } 90 \times 22 \mathrm{~mm} \\
\text { 2nd: Evolution } \\
\text { Duodenal } 90 \times 22 \mathrm{~mm}^{\circledR}\end{array}$ & $81 \mathrm{~d}$ & Yes & $\begin{array}{l}354 \mathrm{~d} \\
(\text { dead })\end{array}$ \\
\hline
\end{tabular}

In all cases, the cSEMS was Hanarostent $90 \times 20 \mathrm{~mm}$. There was $100 \%$ clinical success. Only in case 2, there was no clinical success. y, years; d, days. Survival after cSEMS indicates the duration free of symptoms starting from cSEMS placement until death or until September 2018 in alive patients.

${ }^{1}$ The second uSEMS was placed after recurrence of obstructive symptoms (tumor ingrowth) 203, 134, and 22 days after the first stent in cases 6, 7, and 10 , respectively.

cal treatment was preferred after multidisciplinary team discussion. Exclusion criteria were: (a) no indication for invasive palliative interventions due to the absence of anesthetic conditions or very short life expectancy and (b) absence of follow-up data (minimum follow-up of 15 days).

The clinical records of all patients were evaluated, and the following data were collected: demographics, type of malignancy, site of obstruction, features of the initial uSEMS, technical and clinical outcome, evidence of carcinomatosis, reinterventions, complications, and obstruction-free survival.
Procedure and Equipment

Three fully trained endoscopists with extensive experience in stenting were involved. All stents were deployed under endoscopic and fluoroscopic guidance in patients sedated with propofol. The stenting procedure was always performed with a forwardviewing therapeutic endoscope (GIF 2TH 180; Olympus Medical Systems, Tokyo, Japan) or colonoscope (CF-H180 or CF-HQ190; Olympus Medical Systems) with a 3.7-mm working channel. First, the endoscope progressed to the stenosis site, and subsequently a guidewire was passed through it. A catheter was then placed through the stenosis, and a contrast medium was injected to esti- 
mate stenosis length. Then, a suitable stent length was chosen, considering the shortening of the stent after the extension. Finally, the stent was placed under endoscopic and fluoroscopic guidance.

In all patients, a uSEMS had been placed previously. In this first procedure, the body stent diameter was $22 \mathrm{~mm}$, and length varied $(6,9$, or $12 \mathrm{~cm}$ ); WallFlex (Boston Scientific, Marlborough, MA, USA) or Evolution duodenal or colonic stents (Cook Medical, Bloomington, IN, USA) were employed. After obstructive symptom recurrence, in the second procedure, a partially covered SEMS $20 \mathrm{~mm}$ in diameter and $90 \mathrm{~mm}$ in length (Hanarostent, M.I. Tech, Seoul, Korea) was placed.

\section{Definitions and Endpoints}

Technical success was defined as adequate SEMS placement across the stenosis, confirmed by both endoscopy and fluoroscopy at the end of the procedure. Early and late clinical success was defined as tolerance to food intake, regular stool canalization, and relief of obstructive symptoms, with no procedurerelated adverse events and no subsequent intervention 7 and 30 days, respectively, after the procedure or at the time of death if the patient died before evaluation. Stent dysfunction was considered when there was no clinical improvement because of insufficient SEMS expansion to solve the obstruction, when obstructive symptoms recurred because of stent migration (defined as radiological displacement of stent position after delivery) or restenosis (defined as tumor/granulation tissue ingrowth not allowing passage of a standard gastroscope). Early stent dysfunction was defined as the recurrence of obstructive symptoms within 30 days requiring reintervention; and late stent failure was defined as reintervention more than 30 days after stent deployment [23].

Adverse events included hemorrhage or perforation leading to additional treatment or hospitalization. Perforation was defined clinically, endoscopically, and/or radiologically as the presence of intra-abdominal extraluminal free air only apparent after the procedure of stent delivery.

The presence of carcinomatosis was proven histologically, cytologically, or by imaging, e.g., MRI, CT, or ultrasound. The diagnosis of obstruction was made on the basis of clinical (including surgery), radiological, and/or endoscopic features.

Our primary outcome was clinical success of cSEMS placement (after uSEMS failure). Other endpoints were technical success; stent dysfunction; and adverse events.

\section{Follow-Up}

All patients were followed up from stent placement to the endpoint or death. Stent patency was evaluated in every patient by a radiographic examination at $24 \mathrm{~h}$ (generally with contrast for gastroduodenal obstruction). In the absence of any complications, each patient started a liquid diet within $24 \mathrm{~h}$ of the procedure.

\section{Statistical Analysis}

Statistical analysis was performed using the SPSS software version 21 (SPSS, Chicago, IL, USA). Means and standard deviations (SD) or medians and interquartile ranges (Q25-Q75) (IQR) were used for continuous variables. Frequencies were used for categorical variables. Survival and stent patency time were calculated from the time of cSEMS placement until the time of death or until the last follow-up (September 2018) in living patients.

\section{Results}

\section{Patient Characteristics}

During the study period, cSEMS were placed after uSEMS dysfunction in 12 patients; all were considered as presenting no exclusion criterion (characteristics described in Table 1). The patients included were mostly males $(n=8,66.7 \%)$, and their mean age was $60 \pm 9$ years (range 39-75). At the time of stent placement, 5 patients had ECOG (Eastern Cooperative Oncology Group) performance status 1, 6 had ECOG 2, and 1 patient had ECOG 3. The primary neoplasm was gastric adenocarcinoma in 10 patients and pancreatic carcinoma in 2 cases. Most patients had GOO at the level of the pylorus or duodenum $(n=11)$. The other patient presented obstruction of the transverse colon due to gastric neoplasia compression. Six patients had evidence of peritoneal carcinomatosis. Eleven patients had undergone previous treatments, namely chemotherapy $(n=10)$ and surgery/ chemotherapy/radiotherapy $(n=1)$. In 1 patient, SEMS was the only treatment performed.

Concerning the uncovered stents placed initially, SEMS $22 \mathrm{~mm}$ in diameter was used in all cases, with lengths varying between 60 and $120 \mathrm{~mm}$. Due to tumor ingrowth, 3 patients had a second uSEMS placed 203, 136, and 22 days after the first. The technical success of uSEMS placing was $100 \%$.

After uSEMS placing, there was no early clinical success in 5 cases: the symptoms remained at the 24-h evaluation, likely related to insufficient uSEMS expansion to solve the obstruction. In 2 patients, despite the initial improvement in obstructive symptoms, symptoms recurred after 7 and 29 days (early stent dysfunction). In the remaining 5 cases, late stent dysfunction was observed, with symptoms reappearing after 53-360 days due to tumor ingrowth. Considering the 7 patients with clinically successful uSEMS treatment, median time to dysfunction was 81 days (IQR 29-224). No patient was lost to follow-up.

\section{Technical and Clinical Success of cSEMS after USEMS Dysfunction}

After early or late uSEMS dysfunction, a covered stent (Hanarostent $90 \times 22 \mathrm{~mm}$ ) was placed using the stent-instent technique, aiming to increase the radial strength of the stent and/or prevent tumor ingrowth. In half of the samples, 1 or 2 clips were applied to fix the cSEMS mesh to the prior stent(s) (decision according to the experience of the endoscopist).

There was a $100 \%$ technical success at the moment of stent release and a clinical success of $90.9 \%(n=11)$. In a 


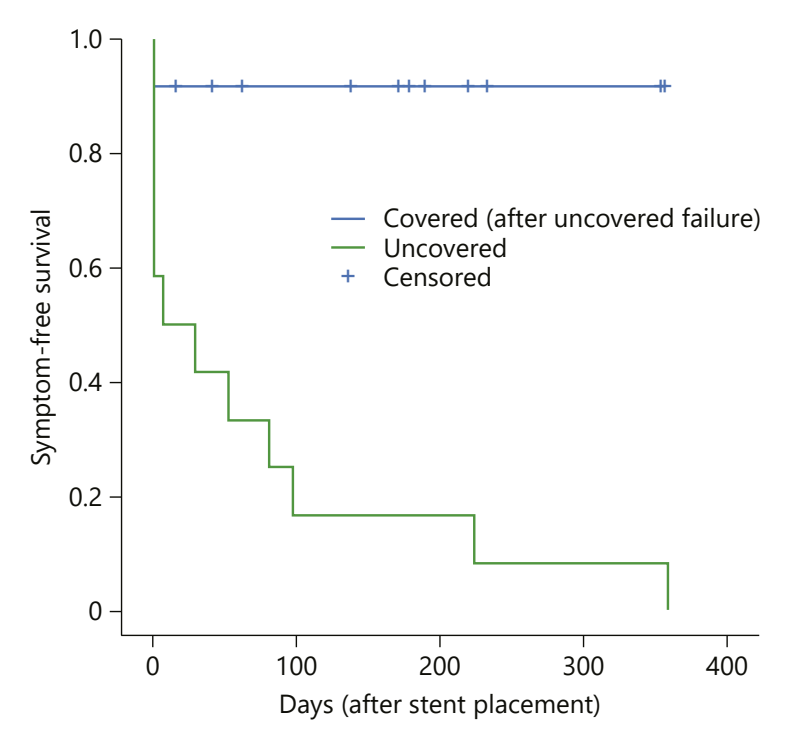

Fig. 1. Kaplan-Meier plot for symptom-free survival according to the type of SEMS. The cumulative symptom-free survival after uSEMS placement was 163 days (vs. 71 days with the initial stent).

patient with relapsing gastric neoplasia in the esophagusjejunal anastomosis and peritoneal carcinomatosis, there was no early clinical success despite good SEMS expansion - a further obstruction downstream was identified gastroduodenally after $24 \mathrm{~h}$; the patient was unable to tolerate oral diet and was started on parenteral nutrition.

In the 11 cases with late clinical success, the median symptom-free survival after cSEMS placement (until death or until September 2018) was 178 days (IQR 62233), with no stent dysfunction occurring in any of these patients (Fig. 1). Reinterventions for secondary stent dysfunction were not required during the same follow-up period. There were no adverse events resulting from cSEMS placement or during the follow-up, namely stent migration, regardless of whether a clip was applied to fix the stent mesh or not.

\section{Discussion}

Endoscopic SEMS placement is widely accepted as palliative treatment for patients with malignant obstruction of the gastrointestinal tract, which is a simple, safe, and effective alternative to more invasive treatments like surgery $[4,24]$. This approach is associated with better quality of life and allows oral nutrition to be reconstituted. However, despite the technical success of SEMS place- ment, clinical success is not as high, and a substantial fraction of patients experience symptom recurrence both early and late after stent placement $[11,24]$.

Stent dysfunction may be due to occlusion following tumor ingrowth and mucosal hyperplasia through the mesh wall or due to stent migration, collapse, or fracture. The rates of restenosis by tumor ingrowth reported in the literature range from 6 to $31 \%$, and restenosis is higher in uSEMS [25-29]. To overcome this problem, cSEMS were developed aiming to prolong stent patency, since the covering membrane prevents SEMS from being embedded into the cancerous lesion or intestinal mucosa. However, the smooth surface of the covering reduces friction between the stent and the bowel wall, and cSEMS have been associated with a higher risk of migration $[4,9]$. Since the migration of SEMS can occur with obstruction or intestinal perforation, this risk represents a major concern for endoscopists [10]. Despite previous studies indicating that uSEMS have a higher rate of restenosis and CSEMS a higher migration rate, a recent systematic review by Hamada et al. [24]. suggested no significant differences in stent dysfunction between covered and uncovered SEMS for nonresectable malignant GOO. Regarding colon obstruction, current recommendations state that covered and uncovered SEMS are equally effective and safe [14].

In the case series presented, we can divide the patients into 2 groups - those that did not show early clinical success with uSEMS placement $(n=5)$ and those with early or late uSEMS dysfunction $(n=7)$. In the first group, clinical success was achieved after placement of the covered stent within the uSEMS in $80 \%$ of patients (without registration of early or late cSEMS dysfunction), and there was no early clinical success in 1 patient with disseminated peritoneal carcinomatosis. We believe that resolution of symptoms in this group of patients with cSEMS was due to the additional benefit of increased radial strength of these stents, which was associated with the covering membrane.

In the second group of patients, despite early clinical uSEMS success, early or late dysfunction was found (after 7-360 days, median time 81 days), which was resolved after cSEMS placement (100\% clinical success in this subgroup). There was no record of cSEMS dysfunction until death or at the end of the follow-up. In this group, probably covered stents bring benefit by preventing tumor ingrowth, decreasing the need for reintervention, and inhibiting early restenosis.

The stent-in-stent technique, with placement of cSEMS after uSEMS, has already been described in obstructions of the esophagus for both stent removal in be- 
nign conditions and for palliative therapy of malignant obstructions that recur due to tumor ingrowth [30]. With respect to the esophagus, few previous studies report on the clinical and technical success of the placement of a second or third stent after dysfunction of the first or second, both in gastroduodenal and colorectal obstructions [16-22]. However, most studies do not only explore the outcome of the uncovered-covered stent combinations, and others include only uncovered or covered stents. Jin et al. [22] reported $100 \%$ technical success and $89.3 \%$ clinical success without the occurrence of adverse events in 28 cases of cSEMS placement after uSEMS dysfunction, which is in agreement with our results. Interestingly, Kim et al. [17] demonstrated that patients who received a second stent due to late complications involving the first stent (migration, restenosis, and fracture) showed a higher clinical success rate than patients who received a second stent due to immediate clinical failure of the first stent. Also, Yoon et al. [19] reported that in lower gastrointestinal tract obstruction longer patency duration of the primary SEMS and absence of carcinomatosis were important predictive factors of immediate and long-term clinical success of stent-in-stent insertion, respectively. In our sample, the only case that did not have clinical success was a patient with immediate failure of the first stent and with peritoneal carcinomatosis. However, even in this case, the stent was able to open the main stenosis, and the reason for clinical failure was the presence of another stenosis below that. In fact, in the other 7 cases in which peritoneal carcinomatosis was present, this approach of cSEMS placement after uSEMS dysfunction was clinically successful.

The duration of patency after placement of the second stent was 178 days in our series, which was comparable to the results of previous studies that evaluated patency after placement of covered and uncovered stents. No specific data on the uncovered-covered stent combination are available.

As in our series, most studies of second stent placement (by stent-in-stent technique) do not report an increased incidence of adverse events. However, Sasaki et al. [18] reported a high rate of severe adverse events, namely perforation rate of $13.8 \%$.

Some case reports and small studies have shown that simultaneous double-stent placement (covered and uncovered SEMS) in the same session seems to be technically feasible and effective for palliative treatment of malignant obstructions $[4,31]$. Indeed, this approach is important since it simultaneously prolongs the duration of stent patency and prevents tumor ingrowth, as well as mi- gration $[4,32]$. However, the simultaneous placement of 2 stents increases the time and costs of the procedure, particularly in patients with short survival times who may not benefit from the longer patency duration due to a short survival prognosis, and therefore the issue of a lower-than-expected efficacy remains to be solved (since it does not solve the problem of noncovered stent migration). Accordingly, the authors consider that, due to the potentially lower risk of migration, an uSEMS, which has sufficient patency time in most cases, should be initially placed. In the event of uSEMS failure, subsequent cSEMS placement may be of greater benefit for improving stent patency. Using this approach, there were no adverse effects in our sample, and the only unsuccessful case was related to peritoneal carcinomatosis, which has already been described as an independent risk factor for SEMS dysfunction. Alternatively, in patients expected to have a short survival, tumor ingrowth fulguration with argon plasma or dilatation is an alternative.

Concerning the higher risk of migration with covered stents, in half of our sample the meshes of the 2 metal stents were fixed to each other with 1 or 2 clips. The possible benefit of clip placement to fix the stents to the mucosa was previously described [33]. In the present series, there were no cases of cSEMS migration, both in the group that was clipped and in the one that was not, and more research is needed to determine the real benefit of this approach.

In addition to clip placement, other mechanisms have been tested to try to decrease cSEMS migration, including modifying stent designs, such as large cup- and large funnel-shaped stents $[9,34-36]$. Although the results are promising with lower migration rates, there appears to be no difference in patency time, and all published studies are performed in small patient cohorts, and comparisons are difficult due to differences in stent characteristics.

An alternative to the approach we described is the use of double-layered SEMS, which consist of an outer uncovered stent designed to reduce migration and an inner covered stent to suppress tumor ingrowth [37]. Using these SEMS, procedure time can be increased without a second intervention, and costs are similar to those of other duodenal SEMS. However, the currently available data show no advantage of double-layered SEMS over cSEMS with regard to patency rate, and experience with these stents is limited. [9].

\section{Limitations}

This study has some limitations. First, it was a retrospective study, with a small number of cases during a 
5 -year period. Second, it was a single-center study, despite being a tertiary referral center. Third, most patients have GOO, with only 1 case of colonic obstruction. The fact that no adverse events have occurred may be due to the small sample. However, it is important to explore this approach in the future in a larger patient cohort to confirm our results. However, to our knowledge, this is the first study that specifically evaluates the technical and clinical success of cSEMS placement after uSEMS dysfunction (cSEMS-uSEMS combination) in malignant obstructions of the digestive tract.

\section{Conclusion}

cSEMS placement after uSEMS dysfunction in malignant obstructions of the digestive tract is technically feasible, simple and safe, with no increase in adverse effects, particularly with regard to the rate of covered stent migration. Taking the results of our initial study as well as the favorable outcomes of this approach using cSEMS after uSEMS dysfunction into account, this may be a solution in cases of complex stenosis, particularly in the presence of obstruction caused by carcinomatosis. Further progress in the stent material and structure may improve the results obtained in this group of patients.

\section{Statement of Ethics}

The study was approved by the Ethics Committee of the Instituto Português de Oncologia do Porto Francisco Gentil, E.P.E.

\section{Disclosure Statement}

The authors have no conflict of interest.

\section{References}

1 Torre LA, Bray F, Siegel RL, Ferlay J, LortetTieulent J, Jemal A. Global cancer statistics, 2012. CA Cancer J Clin. 2015 Mar;65(2):87108.

2 Catalano V, Labianca R, Beretta GD, Gatta G, de Braud F, Van Cutsem E. Gastric cancer. Crit Rev Oncol Hematol. 2009 Aug;71(2): $127-64$.

3 Rothenberger DA. Palliative therapy of rectal cancer. Overview: epidemiology, indications, goals, extent, and nature of work-up. J Gastrointest Surg. 2004 Mar-Apr;8(3):259-61.

4 Song GA, Kang DH, Kim TO, Heo J, Kim $\mathrm{GH}, \mathrm{Cho} \mathrm{M}$, et al. Endoscopic stenting in patients with recurrent malignant obstruction after gastric surgery: uncovered versus simultaneously deployed uncovered and covered (double) self-expandable metal stents. Gastrointest Endosc. 2007 May;65(6): $782-7$.

5 Zhang Y, Shi J, Shi B, Song CY, Xie WF, Chen YX. Comparison of efficacy between uncovered and covered self-expanding metallic stents in malignant large bowel obstruction: a systematic review and meta-analysis. Colorectal Dis. 2012 Jul;14(7):e367-74.

6 Phillips RK, Hittinger R, Fry JS, Fielding LP. Malignant large bowel obstruction. Br J Surg. 1985 Apr;72(4):296-302.

7 Chandrasegaram MD, Eslick GD, Mansfield CO, Liem H, Richardson M, Ahmed S, et al. Endoscopic stenting versus operative gastrojejunostomy for malignant gastric outlet obstruction. Surg Endosc. 2012 Feb;26(2): 323-9.

8 Varadarajulu S, Roy A, Lopes T, Drelichman ER, Kim M. Endoscopic stenting versus surgical colostomy for the management of malig- nant colonic obstruction: comparison of hospital costs and clinical outcomes. Surg Endosc. 2011 Jul;25(7):2203-9.

9 Choe JW, Hyun JJ, Lee DW, Suh SJ, Kim SY, Jung SW, et al. Comparison on the efficacy between partially covered self-expandable metal stent with funnel-shaped enlarged head versus uncovered self-expandable metal stent for palliation of gastric outlet obstruction. Gastroenterol Res Pract. 2018 Apr;2018: 4540138.

10 Kato H, Tsutsumi K, Okada H. Recent advancements in stent therapy in patients with malignant gastroduodenal outlet obstruction. Ann Transl Med. 2017 Apr;5(8):186.

11 Pais-Cunha I, Castro R, Libânio D, Pita I, Bastos RP, Silva R, et al. Endoscopic stenting for palliation of intra-abdominal gastrointestinal malignant obstruction: predictive factors for clinical success. Eur J Gastroenterol Hepatol. 2018 Sep;30(9):1033-40.

12 Masci E, Viale E, Mangiavillano B, Contin G, Lomazzi A, Buffoli F, et al. Enteral self-expandable metal stent for malignant luminal obstruction of the upper and lower gastrointestinal tract: a prospective multicentric study. J Clin Gastroenterol. 2008 Apr;42(4): 389-94.

13 Paúl Díaz L, Pinto Pabón I, Fernández Lobato $\mathrm{R}$, Montes López C. Palliative treatment of malignant colorectal strictures with metallic stents. Cardiovasc Intervent Radiol. 1999 Jan; 22(1):29-36.

14 van Hooft JE, van Halsema EE, Vanbiervliet G, Beets-Tan RG, DeWitt JM, Donnellan F, et al.; European Society of Gastrointestinal Endoscopy. Self-expandable metal stents for obstructing colonic and extracolonic cancer: Eu- ropean Society of Gastrointestinal Endoscopy (ESGE) Clinical Guideline. Endoscopy. 2014 Nov;46(11):990-1053.

15 Pan YM1. Pan J, Guo LK, Qiu M, Zhang JJ. Covered versus uncovered self-expandable metallic stents for palliation of malignant gastric outlet obstruction: a systematic review and meta-analysis. BMC Gastroenterol. 2014 Sep;14:170.

16 Sato T, Hara K, Mizuno N, Hijioka S, Imaoka $\mathrm{H}$, Niwa $\mathrm{Y}$, et al. Gastroduodenal stenting with Niti-S stent: long-term benefits and additional stent intervention. Dig Endosc. 2015 Jan;27(1):121-9.

17 Kim CG, Choi IJ, Lee JY, Cho SJ, Kim SJ, Kim $\mathrm{MJ}$, et al. Outcomes of second self-expandable metallic stent insertion for malignant gastric outlet obstruction. Surg Endosc. 2014 Jan; 28(1):281-8.

18 Sasaki T, Isayama H, Nakai Y, Takahara N, Hamada T, Mizuno S, et al. Clinical outcomes of secondary gastroduodenal self-expandable metallic stent placement by stentin-stent technique for malignant gastric outlet obstruction. Dig Endosc. 2015 Jan; 27(1):37-43.

19 Yoon JY, Jung YS, Hong SP, Kim TI, Kim $\mathrm{WH}$, Cheon JH. Outcomes of secondary stent-in-stent self-expandable metal stent insertion for malignant colorectal obstruction. Gastrointest Endosc. 2011 Sep;74(3): 625-33.

20 Kang MK, Song HY, Kim JW, Kim JH, Park $\mathrm{JH}, \mathrm{Na} \mathrm{HK}$, et al. Additional gastroduodenal stent placement: retrospective evaluation of 68 consecutive patients with malignant gastroduodenal obstruction. Acta Radiol. 2013 Oct:54(8):944-8. 
21 Park JC, Park JJ, Cheoi K, Chung H, Lee H, Shin SK, et al. Clinical outcomes of secondary stent-in-stent self-expanding metal stent placement for primary stent malfunction in malignant gastric outlet obstruction. Dig Liver Dis. 2012 Dec;44(12):999-1005.

22 Jin EH, Kim SG, Seo JY, Im JP, Kim JS, Jung HC. Clinical outcomes of re-stenting in patients with stent malfunction in malignant gastric outlet obstruction. Surg Endosc. 2016 Apr;30(4):1372-9.

23 Mendelsohn RB, Gerdes H, Markowitz AJ, DiMaio CJ, Schattner MA. Carcinomatosis is not a contraindication to enteral stenting in selected patients with malignant gastric outlet obstruction. Gastrointest Endosc. 2011 Jun; 73(6):1135-40.

24 Hamada T, Hakuta R, Takahara N, Sasaki T, Nakai $Y$, Isayama $\mathrm{H}$, et al. Covered versus uncovered metal stents for malignant gastric outlet obstruction: systematic review and meta-analysis. Dig Endosc. 2017 May;29(3):25971.

25 Shin YS, Choi CW, Kang DH, Kim HW, Kim SJ, Cho M, et al. Factors associated with clinical failure of self-expandable metal stent for malignant gastroduodenal obstruction. Scand J Gastroenterol. 2016 Jan;51(1):103-10.

$26 \mathrm{Kim} \mathrm{JH}, \mathrm{Ku}$ YS, Jeon TJ, Park JY, Chung JW, Kwon KA, et al. The efficacy of self-expanding metal stents for malignant colorectal obstruction by noncolonic malignancy with peritoneal carcinomatosis. Dis Colon Rectum. 2013 Nov;56(11):1228-32.
27 Hori Y, Naitoh I, Hayashi K, Ban T, Natsume M, Okumura F, et al. Predictors of stent dysfunction after self-expandable metal stent placement for malignant gastric outlet obstruction: tumor ingrowth in uncovered stents and migration of covered stents. Surg Endosc. 2017 Oct;31(10):4165-73.

28 Kim J, Choi IJ, Kim CG, Lee JY, Cho SJ, Park SR, et al. Self-expandable metallic stent placement for malignant obstruction in patients with locally recurrent gastric cancer. Surg Endosc. 2011 May;25(5):1505-13.

29 Meisner S, González-Huix F, Vandervoort JG, Goldberg P, Casellas JA, Roncero O, et al.; WallFlex Colonic Registry Group. Self-expandable metal stents for relieving malignant colorectal obstruction: short-term safety and efficacy within 30 days of stent procedure in 447 patients. Gastrointest Endosc. 2011 Oct; 74(4):876-84.

30 Vermeulen BD, Siersema PD. Esophageal stenting in clinical practice: an overview. Curr Treat Options Gastroenterol. 2018 Jun;16(2): 260-73.

31 Kim GH, Kang DH, Lee DH, Heo J, Song GA, Cho M, et al. Which types of stent, uncovered or covered, should be used in gastric outlet obstructions? Scand J Gastroenterol. 2004 Oct;39(10):1010-4.

32 Jung GS, Song HY, Seo TS, Park SJ, Koo JY, Huh JD, et al. Malignant gastric outlet obstructions: treatment by means of coaxial placement of uncovered and covered expandable nitinol stents. J Vasc Interv Radiol. 2002 Mar;13(3):275-83.
33 Kim ID, Kang DH, Choi CW, Kim HW, Jung WJ, Lee DH, et al. Prevention of covered enteral stent migration in patients with malignant gastric outlet obstruction: a pilot study of anchoring with endoscopic clips. Scand J Gastroenterol. 2010;45(1):100-5.

34 Lee H, Min BH, Lee JH, Shin CM, Kim Y, Chung $\mathrm{H}$, et al. Covered metallic stents with an anti-migration design vs. uncovered stents for the palliation of malignant gastric outlet obstruction: a multicenter, randomized trial. Am J Gastroenterol. 2015 Oct;110(10): $1440-9$.

35 van den Berg MW, Walter D, Vleggaar FP, Siersema PD, Fockens P, van Hooft JE. High proximal migration rate of a partially covered "big cup" duodenal stent in patients with malignant gastric outlet obstruction. Endoscopy. 2014 Feb;46(2):158-61.

36 Shi D, Ji F, Bao YS, Liu YP. A multicenter randomized controlled trial of malignant gastric outlet obstruction: tailored partially covered stents (placed fluoroscopically) versus standard uncovered stents (placed endoscopically). Gastroenterol Res Pract. 2014;2014: 309797.

37 Park CI, Kim JH, Lee YC, Jahng J, Youn YH, Park $\mathrm{H}$, et al. What is the ideal stent as initial intervention for malignant gastric outlet obstruction? Dig Liver Dis. 2013 Jan;45(1):33-7. 